\title{
Research on the Application of Archives and Historical Materials in the Study of the History of the Republic of China (1912-1949)
}

\author{
Shidong Pei ${ }^{1}$, Qihang Wang ${ }^{2}$ \\ ${ }^{1}$ School of Social Development, Nanjing Normal University, Nanjing 210023, China \\ ${ }^{2}$ Department of History, Anhui University, Hefei 230039, China \\ Email: psdlyy@gmail.com
}

\begin{abstract}
The history of the Republic of China is a very important history in the modern history of our country. During this period, great changes took place in China and the Revolution of 1911 abolished monarchy; then the Communist Party of China led the Chinese people in the struggle for national liberation and established the People's Republic of China. Therefore, studying the history of the Republic of China is an inevitable requirement for historical development. To this end, this article starts with exploring the research connotation and value of the history of the Republic of China, comprehensively collects archival historical data, insists on using the historical materialist methodology to conduct research on the history of the Republic of China, and discriminates historical materials objectively and fairly. Three aspects have been studied and discussed.
\end{abstract}

Keywords: history, the Republic of China, archives, historical materials, application

\section{Introduction}

History of the Republic of China is an emerging discipline in the field of Chinese history. In the past, there was not much research in this area. The real start was after the Third Plenary Session of the Eleventh Central Committee of the Party in 1978, which established the party's ideological line of seeking truth from facts. Therefore, as far as its research content is concerned, there are many major issues that need to be explored in order to restore history. To achieve this, it is necessary to fully mobilize and make use of various archives and related historical materials during the Republic of China, evaluate the relevant events and figures in a realistic and objective manner, and provide service support for the construction of China's ad hoc socialist modernization. .

\section{A brief description of the research connotation and value of history of the Republic of China}

\subsection{The research connotation of the history of the Republic of China}

In 1911, the revolutionaries led by Sun Yat-sen launched an uprising in Wuchang, overthrew the Qing government, and ended the feudal monarchy of China for thousands of years. On December 29, 1911, a temporary presidential election meeting was held in Nanjing, where Sun Yat-sen was elected. He was the interim president, officially taking office on January 1, 1912, promulgating the country name as the Republic of China, and no longer using the imperial year name, and taking January 1, 1912 (the emperor era November 13, 4609) as the Republic of China. On the New Year's Day of the first year, the Gregorian calendar was used ${ }^{[1]}$. As a result, the history of the Republic of China officially began to be written. Since then, a melee situation of warlord separatism and the Northern Expedition led by the Kuomintang and the Communist Party have emerged ${ }^{[2]}$. After Chiang Kai-shek usurped the leadership of the Kuomintang, he changed the original intention of Sun Yat-sen's revolution, undermined the good situation of the KMT-CCP cooperation, and sworn against the Communist Party of China representing the interests of the broad masses, until the founding of the People's Republic of China on October 1, 1949. The end of the Republic of China. It can be seen that from the perspective of time, the history of the Republic of China should be from January 1, 1912 to September 30, 1949.

\subsection{The research value of the history of the Republic of China}

First of all, the history of the Republic of China is an important part of Chinese history, especially Chinese modern history. In this period of history, China has undergone earth-shaking changes: first, the Revolution of 1911 overthrew the Qing government and ended the feudal monarchy for thousands of years; second, the second cooperation between the Kuomintang and the Communist Party, which defeated the Japanese invaders; third, the leadership of the Chinese Communist Party The Chinese people waged a national liberation struggle and established a new China ${ }^{[3]}$. Secondly, after 
the 1911 Revolution, China's productivity and production relations have made unprecedented progress, and our national industry has begun to rise and develop. Thirdly, in the field of culture and education, the rise of the May Fourth New Cultural Movement, abandoning eight-stranded texts, and advocating vernacular texts, can be called a revolution in the cultural education field. In short, there are many things worth studying in the history of the Republic of China. To explore the people and events in this history, one is to clear the source, the other is to inspire future generations, and the third is to achieve the peaceful reunification of the motherland as soon as possible ${ }^{[4]}$.

\section{The comprehensive collection of archival historical data is the premise and basis for studying the history of the Republic of China}

\subsection{The relationship between history and historical materials}

What is history? It is an objective existence that has passed away, and it cannot be repeated or reproduced. To understand history and history, we must study history. In order to study history, you must read and consult a large number of archival historical materials. Therefore, archival historical materials are the basis and basis for studying history. Imagine that without archival historical materials as the basis, history cannot become an independent discipline, and history has become a rice-free cook and a wood without a root ${ }^{[5]}$.

\subsection{Classification and function of historical data}

According to the source form, historical data can be divided into two categories: historical texts and non-textual historical data, and can also be divided into: historical texts, physical historical data, customs historical data and reputation historical data. Among them, the textual historical data is an important historical data among various historical data, and the archival historical data in the textual historical data is the top priority among the historical data. Because archival historical materials are unpublished written materials formed in social practice by government departments, party and government agencies, factories and mines, etc., their reliability and authenticity are relatively strong ${ }^{[6]}$.

\subsection{Archival historical materials are the basis for studying the history of the Republic of China}

First of all, archival historical data can provide a wealth of first-hand historical data for the study of the history of the Republic of China. The archive itself has the characteristics of recordability, authenticity, and originality, and is a true record of the activities of the government, departments, and their personnel. We cannot study the history of the Republic of China without the historical data of important people, such as Sun Yat-sen, Mao Zedong, Chiang Kai-shek, etc. Correspondences, correspondence, and meeting records related to these important people can be regarded as precious source materials, which is important for studying the history of the Republic of China in accordance with. Secondly, archives are also an important basis for historical writings and selection of historical materials. This is due to the fact that the archives were the original data formed at the time and are relatively accurate. Oral materials, newspapers, magazines, and memoirs are written materials after the fact, or even years later. It is inevitable that there will be inaccurate memories or other facts that deviate from the truth. For example, in his book "My Memories", Zhang Guozheng boasted about how he fought against Beiyang warlords in prison after his arrest in 1924 by the Beiyang government. In fact, the Ministry of Internal Affairs of the Beiyang Government consulted in the Second Historical Archives of China learned that during the interrogation of Zhang Guozheng, Zhang Guozheng not only had defected, but also provided the early leaders of our party such as Chen Duxiu, Li Dazhao and others ${ }^{[7]}$.

\section{Persist in the study of the history of the Republic of China with the historical materialist methodology}

Materialists believe that material determines consciousness, history is an objective existence that has passed away, it is an objective fact of the past, and it is a historical fact that is not transferred by anyone 's will. The conditions for studying the history of the Republic of China are much better than the conditions for studying ancient history; first, time is near, and second, there are more historical materials. However, if the research conditions are good, it can't be said that you can do good research. You also need to have a certain, critical, and thinking ability to use good historical data. You must analyze and judge based on a large collection of historical data to improve the authenticity of screening. The ability of pseudohistorical materials effectively overcomes the subjective one-sided situation in the use of archival historical materials ${ }^{[8]}$. Specifically, these points must be overcome. 


\subsection{Many types of historical materials, but less attention to the content of historical materials}

As far as the formation of archival historical materials is concerned, he is a record of historical activities, and its reliability and authenticity are relatively strong. However, because the social nature of the Republic of China is still a semi-feudal and semi-colonial social nature, it is impossible for the interests of the ruling class to serve as the archives and historical materials of the state's memory, and it is impossible to serve its political consolidation without being limited by the times. Therefore, as a current researcher of the history of the Republic of China, not only should the records of the historical data of the research objects exist, but also the comprehensive analysis of the content of the records to ensure the authenticity of the historical data ${ }^{[9]}$.

\subsection{Attaching importance to the role of archival historical materials and ignoring the evidence of other historical materials}

Archival historical materials are original records of historical activities of governments, departments, and institutions, and their authenticity and reliability are very strong. Most of the newspapers, magazines, photos and images during the Republic of China were run by the government. For political purposes, it is inevitable that they are not true. However, the role of these historical materials cannot be ignored because of this. In fact, the newspapers and magazines of the Republic of China were a new type of media that appeared in modern times. The amount of information transmitted by them was extremely wide. It can be said that they covered the political, economic, cultural, and social issues at that time. In all aspects, it has great reference value and utilization value. First, all historical activities during the Republic of China had archive records and documents, but newspapers and magazines made up for this deficiency. Second, many archival historical materials of the Republic of China were scribbled and damaged, and the phenomenon of serious damage was missing. The use of newspapers and magazines and other historical materials It can be compared with other historical materials, such as newspapers and magazines, and mutually corroborated. This is also in line with the principle of "no evidence" in historical academic norms ${ }^{[10]}$.

\section{Screen historical materials objectively and impartially, and provide empirical evidence for the study of the history of the Republic of China}

The study of the history of the Republic of China must be based on the archives of the Republic of China. However, it cannot be said that archival historical materials are the basis of research, and the existence of other factors is not considered, such as falsifying the records of historical archives. This is also a summary and reference of historical experience. For example, in a city under the Wang Puppet Regime, there are 1033 members of the KMT in 1939, and 1033 copies of the KMT registration form are filled in. The contents include photos of the party members, signatures, stamps, and home addresses. And even fingerprints. However, after investigation, of the 1033 people, 609 of them were registered by the Kuomintang. They were faked by Wang pseudo-partisans to make money for promotion, took advantage of subsidies, re-photographed from the school roster, forged the registration form, and submitted it to the Kuomintang City Party Department. The archives and historical materials were finally preserved. Although this case is a case, it tells us the fact that, as a researcher of the history of the Republic of China, as a researcher of the history of the Republic of China, he must attach importance to the excavation of archival historical data, and unswervingly regard it as the only one basis to check the authenticity.

\section{Summary}

It is important to study the history of the Republic of China to collect archives and historical data, which is the basis and prerequisite for the study. However, it is more important and crucial to make good use of archives and historical materials to better serve the study of the history of the Republic of China. In the research process of the history of the Republic of China, we must follow the historical materialist methodology to analyze, identify, and verify the archives and historical materials in order to make the existing archives and historical materials play the greatest role and be of the greatest value.

\section{References}

[1] Zhang Qiang. (2012) A Review of the Research on the History of the Republic of China on the Center for the History of the Republic of China at Nanjing University. Master's Thesis, Yangzhou University, Yangzhou.

[2] Yang Nianqun. "Break" or "Continuation"? - Thinking about How to Learn Traditional Resources from the History 
of the Republic of China. Journal of Nanjing University (Philosophy, Humanities, Social Sciences). 2013; 50(1): 108112 .

[3] Wang Chaoguang. Research on the History of the Republic of China for 50 Years. Modern Chinese History Studies. 1999; (5): 157-177.

[4] Chen Qianping. International Development: A New Perspective on the History of the Republic of China. Modern Chinese History Studies. 2012; (1): 133-137.

[5] Jiang Boying. Several Issues in the Study of the History of the Republic of China. DANGSHI YANJIU YU JIAOXUE. 1986; (2): 57-58.

[6] Chen Qianping, Chen Hongmin, Zhang Sheng. Review of the Fourth International Symposium on the History of the Republic of China [J]. Historical Research. 2001; (1): 184-188.

[7] Zhang Xianwen. A Brief Account of the Academic Seminar of the Republic of China Archives and History of the Republic of China. Historical Research. 1988; (2): 187-192.

[8] Wang Jianlang. New Achievements and New Hopes: a Written Talk on the Publication of "The History of the Republic of China" - from the Perspective of the Republic of China. Modern Chinese History Studies. 2012; (1): $131-133$.

[9] Wu Jingping. Thoughts on the Object and System of the History of the Republic of China — from the Publication of Archives and Historical Materials of the Republic of China. Journal of Historical Science. 2018; (12): 118-125.

[10] Qi Chunxiao. On Archives and Studies of the History of the Republic of China. Lantai World. 2007; (22): 10-11. 